\title{
The Significance of Atheistic Humanism of E.V.Ramasamy
}

\author{
S. Gunasekar \\ Associate Professor, Department Of Philosophy, National College, (Affiliated To Bharathidasan University) \\ Tiruchirapalli - 620001 Tamilnadu, India
}

\section{Introduction}

Philosophy in the West had the anti-metaphysical inclinations as its basis in the beginning of twentieth century. It witnessed an increase in secularization and a decline in religious credence. In this period humanism has come to refer to a philosophy that rejects traditional religious dogmas and regards humans as capable of using their intelligence to live their lives. Humanism is not new to Indian traditions. It differs from mysticism, asceticism and religion. In India humanism has a long illustrious history which dates back to Carvaka (the materialist) and Buddha.

The man made evils like caste system and gender biases are the nauseating conceptions of selfish people with vested interests for the exploitation of the oppressed prevailed in India. Only few wise persons raised their voices against these evils, have kindled and awakened the society and given an inexorable fight against the prevailing social order of their times in order to free the people from the fetters imposed on them, have become eternal individuals in the history. Mahatma Phule, Ambedkar, M.N.Roy, E.V.Ramasamy and many other social reformers raised their voices against the deteriorating and manipulative forces rooted in the society. This paper is an attempt to bring to limelight the philosophy of atheistic humanism of E.V.Ramasamy.

\section{Significance Of The Study}

E.V.Ramasamy was branded as an atheist and anti-brahmin by a section of people. He was popularly known as an atheist and a reformer. But in reality he is beyond an atheist and above a reformer. He is a philosopher that too a humanistic philosopher. No one can under estimate his humanistic attitude on the basis of his anti-brahminical tendencies alone. His anti-brahminical attitude has never been a hurdle to his humanistic approach. The Brahmins consist of two per cent population but exploiting the majority, consisting of ninety eight per cent of the population. E.V.Ramasamy was forced to wage a war against this exploitation. It was the need of the then period. The social evils such as untouchability, casteism, superstition, foolish dogmas, all emanated from the belief in god. Hence to eradicate the evils he had to become an atheist. His untainted atheistic principles are objective and rational. His principles started with atheism as a weapon supported by rationalism and culminate in humanism. E.V.Ramasamy was branded as a core atheist, like Mahatma Gandhi who was regarded as a mere Father of the Nation and Saint Ramalingar as a mere religious reformer. It is well known that the contributions of Mahatma Gandhi and Saint Ramalingar to the society and philosophy are enormous. Likewise, E.V.Ramasamy's contribution to philosophy is also immense. The aim of this study is to project E.V.Ramasamy's contribution to philosophy as an atheistic humanist.

\section{E.V.Ramasamy - A Unique Personality}

E.V.Ramasamy (1879-1973) was born in $19^{\text {th }}$ century and brought up in an orthodox Hindu family. He was a man with extraordinary intellectual acumen. He was an original eminent thinker. Though he declared himself in public an atheist, he was a great campaigner of humanism. He was a great humanist par excellence.

He was very perceptive to the problems of the depressed and oppressed. He wished to change the Dravidian society into a society with pride and knowledge. With all humility he submits that "I took this task because nobody has thought over it". He proclaimed that he was the fittest person to undertake the work because he had no attachment in anything and his thoughts are rooted in rationalism. He thought that blind faith can be annihilated through destructive methods only. This is possible for a man with firm determination, with impeccable thought, uncaring for slander and death.

E.V.Ramasamy spent more than half of his life time working towards educating the people through his speeches and writings. He worked relentlessly over 50 years not for his personal benefit and securing positions in society but only for serving the humanity. He advised that the duty and the responsibility of the rationalist are to work with reason, without any second thought. Rationalist considers all countrymen as one. Rationalism is clarity with evidence. Rationalism is the live wire of man. If a man gets clarity in reason he is ripened in his rationalism. The aim of the rationalist is to live a life of a layman. Not to inflict pain on the living beings is the outcome of rationalism. These are the views of E.V.Ramasamy. 
He proclaimed that one should serve the society irrespective of nation, language, god, religion, caste. A social reformer should not attach himself to god, nation, religion, sastra, purana, ancient literature, and language. Man should work to make a man a man. That which is not suitable to reason, which brings shame to reason should not be accepted. If one wants name, fame and happiness, he should compete with others in doing service to fellow beings. He declared that, "To reform the Dravidians and help them to evolve a civilised and intellectual society as all other peoples in the world, is my primary endeavour which I myself have taken upon my shoulders as my way of life and to which I have dedicated myself whole-heartedly. One need not be carried away by the mere consideration that a certain concept is believed or practised by numerous people and for many years; but one should take care to analyse and think over about everything carefully and to enquire himself whether it stands to his reason and experience and only after he is fully satisfied that what he has found is really correct, he may take it and follow it". ${ }^{1}$ E.V.Ramasamy was of the opinion that reform is eliminating the unnecessary and keeping the necessary things. He staunchly feels that that is real reform where there is no poverty and where people do not live at the cost of conscience. He vociferously said that political freedom must be preceded by social reform and social unity.

\section{Social Activities Of Self-Respect Movement}

In 1925 E.V.Ramasamy started the Self-respect Movement. The objectives of the Movement were striving for establishment of a casteless society based on complete equality, eradicating all social evils and freeing the society from the shackles of superstitions and blind faith, to strive for complete educational and employment opportunities to women in all spheres as in the case of men, to popularise the Self-Respect Marriages (conducted without any priests and religious rituals) and to propagate rationalism. Self respect life is free life. "First we are men then only we are Indians." This is the motto of self respect movement.

This Movement's most important objective was to obtain the communal justice by way of reservations in educational institutions and in Government jobs to the vast majority of the masses. E.V.Ramasamy made it clear that such communal justice should be rendered as long as castes existed. ${ }^{2}$ Dr.B.R.Ambedkar also wished to change the society into a society with pride and knowledge. To him, it is shameful to live at the cost of one's self respect. Self-respect is a most essential aspect in life. Without it man is a cipher. To live admirably with self-respect one has to conquer intricacies. It is out of firm and unending effort alone that one acquires vigour, self-reliance and acknowledgment in the society. One should determine to lay down one's life in elevating the splendid principles of self-respect and in enhancing human life. Humans are not slaves. Nothing is more shameful for a courageous man than to live a life devoid of self-respect. The effort is for respect not only for the economic growth alone. Self-respect is more essential than the economic gains. ${ }^{3}$

E.V.Ramasamy proclaimed that the Self-Respect Movement was launched with a view to instilling a sense of dignity and respect among all men. It also aimed at effecting a radical change among men and women by making them undergo a social revolution with its concomitant trials and tribulations. In many respects, it is we who are responsible for our abjectness and degradation. Unless we move towards religious reformation and social changes, a revolution in society is next to impossible. ${ }^{4}$ It is a birth right of every one to lead a respectable life. By giving education to the oppressed people, the caste system will be driven away. Rights are protected not by law but by the social and moral conscience of society. To attain this endeavor one must do his utmost.

He must be ready to make the utmost sacrifice for reaching this end. There is no honour in mere survival. What matters is the plane of survival.

The movement launched by E.V.Ramasamy had distinct remarkable implication and consequence. He fought for human self-respect which the vested interested people had thus far denied to the oppressed. His desire was to build our life as full and wholesome as possible. To him, everyone is an equal citizen and the differences on the basis of caste and creeds were man-made to keep the innocent and ignorant as oppressed in the society. UNESCO commended the greatness of the selfless public service of E.V.Ramasamy in a citation which reads,

"Periyar the Prophet of the New Age;

The Socrates of South East Asia;

The Father of the Social Reform Movement

And arch enemy of Ignorance, Superstitions,

Meaningless customs and baseless manners". Nadu, India. ${ }^{5}$

This honour was bestowed during his lifetime on $27^{\text {th }}$ June 1970 by UNESCO Forum at Chennai, Tamil

The former Chief Minister of Tamil Nadu State of South India, C.N.Annadurai when eulogising the personality of E.V.Ramasamy, says "An aged man who has not seen the college; who was of a boisterous type from his early days! An agitator who knew not that a party should be organised with a political motive, who never yielded to tactful ways on account of the fear that his thoughts might hurt the hearers and induce them to 
slander him, who had to face the hard kicks from those whom he had buttressed and brought up, who never thought of adjusting himself to suit the persons whom he contacted who had no support of the popular English and Tamil dailies, who turned a deaf ear to those who advised him not to ruin himself by attacking the religions and gods". ${ }^{6}$ One of the ideals of E.V.Ramasamy, the Self-Respect Marriage materialised in the reign of C.N.Annadurai. Dr.C.N.Annadurai assumed the Chief Ministership in 1967 and passed in the Assembly the Self-respect Marriages Act. He dedicated his ministry to E.V.Ramasamy as a token of respect for his devoted and selfless services to humanity. E.V.Ramasamy firmly believes that ultimately rationalist will triumph.

E.V.Ramasamy held that next to self-respect, the social reformers should concentrate on the equality of men and women. In our society women are treated worse than untouchables. Women are considered to be slaves of men. If such a system has been made by god, the first thing that we should do is to destroy that god. It is a great pity that so many things should be foisted upon the devoted head of poor god. Especially in our country, the position of our womenfolk is the worst that could be thought of. Chastity is considered to be the foremost duty of women. ${ }^{7}$ Ever since the inception of Self-Respect Movement, E.V.Ramasamy had propagated the equality of men and women, their equal rights in law and in social life. He bestowed as much time and attention for propaganda on raising the state of women as on abolition of untouchability and caste inequality. ${ }^{8}$

He recommended family planning to achieve freedom and rights of women. To him, the slavery of women was the degradation of civilization. He suggested certain concrete steps to bring about equality. He considered that by reserving 50 per cent of jobs to women, the desire for having male child could be checked.

This would also help in family planning and that women's employment itself would directly lead to birth control. ${ }^{9} \mathrm{He}$ is the first leader who suggested family planning on economic, social and health grounds. He advocated the right to property for women.

To E.V.Ramasamy, slavery of women is the destruction of mankind. Life contract is meant that a male and female should lead life of friends. If women are educated then men will become moral. If women are given liberty, male harassment will go away. A civilized woman is one who roars that she has equal status, equal rights and equal freedom. Family planning is necessary for women to enjoy freedom and individual rights.

Women with reform thinking and reason can give birth to children with reason and reform thinking. Manhood is the term which ruins the womanhood. If womanhood destroys the manhood then only there will be freedom for women. Men should understand and accept that like an elephant, woman also have valour, anger and governing power. Woman is a slave and an inert thing is the meaning given to the term Chastity. If there is chastity then it should also exists for man. ${ }^{10}$ If widows are re-married, the country will have able bodied citizens in future. If atheism and liberty for women are scrupulously followed, the whole of India will become highly progressive in the nations of the world.

\section{Conclusion}

E.V.Ramasamy was not only a man of words but also a man of deeds. He spoke and wrote many a time about honesty, integrity, propriety and a host of other virtues. The greatness of E.V.Ramasamy was that he never stopped with preaching but also practised what he preached. Moreover, he expected his followers to adhere strictly to his principles. Those who deviate from him would cease to be his followers. His contributions to the mental emancipation were immense. ${ }^{11}$ He thought that his movement should continue even after him for which he made some arrangements. He opines that it is not enough that youth have mere enthusiasm and sacrifice. They should also have the analytic power to distinguish between good and bad or else they will become a prey in the hands of selfish people. To achieve this he created selfless volunteers to propagate humanist rationalism. His missionary zeal established a trust in 1952 by the name "Periyar Self-Respect Propaganda Institution". He published cheap edition books, periodicals, etc., to cater to the people of Tamil Nadu under this Trust. He donated a lump some money to establish an Arts and Science College (EVR College) at Tiruchirapalli, South India, which still exists. He donated sizable amount for improvement of Government hospitals and he started training schools for women and men, a child care centre and a Higher Secondary School for girls. This shows that he practiced what he preached and he preached what he thought.

\section{The golden words of E.V.Ramasamy are quoted here to conclude:}

"I am a free man. I have free thought, free experience and free feeling in me. I propose these three to you. Like me you also consider with your free thinking, free experience and feeling, accept whatever is acceptable and reject whatever is unacceptable. This is applicable to all human beings in what so ever field they may belong to". He should not be misjudged as mere atheist. His service to the society as a humanist cannot be underestimated.

\footnotetext{
Notes

1. E.V.Ramasamy - An Anthology, The E.V.Ramasamy Self-Respect Propaganda Institution, Madras, 1992 , p.123.

2. Ibid., p.125.

3. Thangaraju, P., Selected Thoughts of Dr.Ambedkar, Puratchikkanal Publications, Madras, 1996, p.36.
} 
4. Ibid., p.114.

5. Veeramani, K. Dr., (compiled by), Collected Works of Periyar E.V.R., The Periyar Self-Respect Propaganda Institution, Chennai, 2005, p.36.

6. E.V.Ramasamy - An Anthology, The E.V.Ramasamy Self-Respect Propaganda Institution, Madras, 1992, pp.4-5

7. Pakuttharivalar Kalaga Kaiyedu (Tamil version), Pakuttharivalar Kalagam, Thanjavur, 1976, p.95.

8. Saraswathi,S., Towards Self-Respect E.V.Ramasamy EVR On a New World, Institute of South Indian Studies, Madras, 1994, p.193, 194.

9. $\quad$ Ibid., p.195.

10. Palanisamy,T. E.V.Ramasamy Kanda Paerunmaigal, Manivasakar Pathippagam, Chennai, 1997, pp.61-65.

11. Palany Arangasamy (trans.), Gopalakrishnan (compilation), Is there a God?, Emerald Publishers, 1996, pp.ix and x.

\section{References}

[1]. A.S.K., E.V.Ramasamyum Ambedkarum (Tamil version), Meena Gopal Pathippagam, Chennai, 2004.

[2]. Arijnar Anna, E.V.Ramasamy Oru Sagaptham, E.V.Ramasamy Suyamariyadhai Prachara Niruvana Veliyeedu, Chennai, 2005.

[3]. Palanisamy, T. E.V.Ramasamy Kanda Paerunmaigal (Tamil version), Manivasakar Pathippagam, Chennai, 1997.

[4]. Palany Arangasamy (trans.) Gopalakrishnan (compilation), Is there a God?, Emerald Publishers, 1996.

[5]. Prema Aravindan, E.V.Ramasamyin Ponmoligal, Swamimalai Pathippagam, Chennai, 2005.

[6]. Saraswathi,S., Towards Self-Respect E.V.Ramasamy EVR On a New World, Institute of South Indian Studies, Madras, 1994.

[7]. Thangaraju, P., Selected Thoughts of Dr.Ambedkar, Puratchikkanal Publications, Madras, 1996.

[8]. Thanthai E.V.Ramasamy, Samudaya Seerthirutham (Tamil version), E.V.Ramasamy Suyamariyadhai Prachara Niruvana Veliyeedu, Chennai, 1999.

[9]. Veeramani, K. Samuga Neethi (Tamil version), Dravidar Kalaga Veliyeedu, Chennai, 1998.

[10]. Veeramani, K., E.V.Ramasamyin Samudaya Ariviyal Paarvai (Tamil version), Dravidar Kalaga Veliyeedu, Chennai, 2001.

[11]. Venu, A.S., E.V.Ramasamy Oru Charithira (Tamil version), Poompuhar Pathippagam, Chennai, 2000

[12]. Visswanathan Dr.E.Sa., The Political Career of E.V.Ramasami Naicker, Emerald Publishers, 1996.

[13]. E.V.Ramasamy - An Anthology, E.V.Ramasamy Self-Resopect Propaganda Institution, Madras, 1992.

[14]. Pakuttharivalar Kalaga Kaiyedu (Tamil version), Pakuttharivalar Kalagam, Thanjavur, 1976. 